\title{
MITES (ACARI) ASSOCIATED WITH BAMBOO (BAMBUSA SP., POACEAE) IN A WOODY AREA FROM NORTHWESTERN SÃO PAULO STATE, BRAZIL
}

\author{
Reinaldo J.F. Feres ${ }^{1}$ \\ Carlos H.W. Flechtmann ${ }^{2}$
}

\begin{abstract}
This paper reports twelve acarine species belonging to eleven genera in five families, associated with Bambusa sp. (Poaceae), in a woody area from São Paulo State, Brazil. Four species of Tetranychidae (Monoceronychus bambusicola, sp.n., Oligonychus santoantoniensis, sp.n., Schizotetranychus longirostris, sp.n. and $S$. paraelymus, sp.n.) are regarded as new. The genus Cheletomimus Oudemans. 1904 (Cheyletidae) is recorded for the first time to South America.

KEYWORDS. Acari, mites, bamboo, taxonomy
\end{abstract}

The study of the mite fauna associated with Bambusa sp. (Poaceae) was conducted in one woody area, with two large clumps of this plant from "Sítio Santo Antônio" (Small farm - 49¹7`45"W, 2050’26"S), São José do Rio Preto (São Paulo, Brazil).

Twelve mite species belonging to eleven genera of five families were recorded. Four species of Tetranychidae are regarded as new. The genus Cheletomimus Oudemans, 1904 (Cheyletidae) is recorded for the first time to South America:

Phytoseiidae

Amblyseius zuluagai (Denmark \& Muma, 1972)

Euseius citrifolius Denmark \& Muma, 1970

Typhlodromus sp.

Cheyletidae

Cheletomimus duosetosus Muma, 1964

Hemicheyletia wellsi (Baker, 1949)

Tydeidae

Lorryia formosa Cooreman, 1958

Tydeus sp.

Tetranychidae

Monoceronychus bambusicola, sp.n.

1) Departamento de Zoologia, Universidade Estadual Paulista. Caixa Postal 136, 15054-000 São José do Rio Preto, São Paulo. Brasil.

2) Departamento de Zoologia, Escola Superior de Agronomia Luiz de Queiroz, Universidade de São Paulo. Caixa Postal 9, 13418-900 Piracicaba, São Paulo. Brasil. Bolsista CNPq. 
Schizotetranychus longirostris, sp.n.

Schizotetranychus paraelymus, sp.n.

Oligonychus santoantoniensis, sp.n.

Winterschmidtiidae

Czenspinskia sp.

Phytoseiidae were named according to CHANT (1965), modified by CHANT et al. (1978), MCMurtry (1983) and Chant \& Yoshida-Shaul (1986). Setal nomenclature is that of RowELL et al. (1978) for dorsal surface. The Tetranychidae setal nomenclature is according to GRANDIEAN (1939) and LINDQUIST (1985) and in parentheses, equivalent notations used after JEPPSON et al. (1975).

Morphological characteristics of species have been determined by using phase and interference contrast microscopy. Measurements are given in micrometers $(\mu \mathrm{m})$. The body lenght included the rostrum. The range of measurements are shown in parentheses.

The holotypes are deposited in the Depto. de Zoologia, Universidade Estadual Paulista (UNESP), São José do Rio Preto, São Paulo, Brasil. Paratypes and moreover specimens are in same collection as holotypes and in senior author's collection.

\section{Phytoseiidae Berlese, 1916}

\section{Amblyseius zuluagai (Denmark \& Muma, 1972)}

Iphiseiodeszuluagai Denmark \& Muma, 1972: 23. - Denmark \& Muma, 1973: 251. - Denmark \& Muna, 1975: 287.

Amblyseius zuluagai Moraes \& Mesa, 1988: 79. - Moraes: Mesa \& Braun. 1991: 125-126.

Specimens examined. Brazil, São Paulo: São José do Rio Preto (Sítio Santo Antonio), three females, IV-21-1990.

Previous records. Brazil, Colombia, Puerto Rico, Cuba, Panama (MoraEs et al. 1991).

\section{Euseius citrifolius Denmark \& Muma, 1970}

Euseius citrifolius Denmark \& Muma, 1970: 222. - Moraes \& McMurtry. 1983: 138.

Specimens examined. Brazil, São Paulo: São José do Rio Preto (Sítio Santo Antonio), nine females and two males, V-28, VI-21 and VII-23-1990.

Previous records. Brazil (Bahia, Ceará, Paraíha, Pernambuco, São Paulo), Paraguay, Peru (Moraes et al. 1986), Colombia and Nicaragua (MORAEs et al. 1991).

Remarks. On the average, the specimens have longer j4-j6, r3 and R1 setae when compared to the measurements given in the original description. These data agree with those of MORAES \& MCMURTRY (1983), for specimens from Brazil. However, $j \mathrm{l}$ and macrosetae of leg IV are of equal size (shorter in MORAES \& MCMURTRY 1983). 
The average measurements and the range (shown in parentheses) of six females measured are compared with the corresponding measurements in the original description (in heavy-faced type): j1 28 (27-30)28, j4 13 (11-14)7, j5 12 (11-14)8, j6 15 (14-16)8, r3 18 (16-22)11, R1 15 (14-16)8, Sge IV 44 (41-46)47, Sti IV 34 (32-35)34, St IV 60 (57-62)58.

\section{Typhlodromus sp.}

This species is being described by Dr. Gilberto J. de Moraes (EMBRAPACNPMA, Jaguariúna, São Paulo, Brazil), based on specimens collected from Colombia (personal comunication).

Specimens examined. Brazil, Sào Paulo: São José do Rio Preto (Sítio Santo Antonio), two females; VI-21-1990.

\section{Cheyletidae Leach, 1814}

\section{Cheletomimus duosetosus Muma, 1964}

Cheletomimus dunsetosus Muma, 1964: 242.

Specimens examined. Brazil, São Paulo: São José do Rio Preto (Sítio Santo Antonio), one female and three nymphs, IV-26, V-28 and VI-27-1990.

Previous records. USA (MUMA 1964).

\section{Hemicheyletia wellsi (Baker, 1949)}

Cheyletia wellsi Baker. 1949: 300-301.

Paracheyletia wellsi Volgin, 1955: 152. - Muma, 1964: 245-246.

Hemicheyletia wellsi Summers \& Price. 1970: 18.

Specimens examined. Brazil, São Paulo: São José do Rio Preto (Sítio Santo Antonio), two females, V-28-1990.

Previous records. Africa (Rodrigues 1968), Brazil (São Paulo) (FlechtMANN 1971), USA (MUMA 1964).

\section{Tydeidae Kramer, 1877}

\section{Lorryia formosa Cooreman, 1958}

Lorryia formosa Cooreman, 1958: 7.

Specimens examined. Brazil, São Paulo: São José do Rio Preto (Sítio Santo Antonio), six temales and three nymphs, V-30-1988, VI-21 and VII-23-1990.

Previous records. Argentina, Brazil, Ecuador, Spain, France, Marrocos, Mexico, Uruguai (BAKER 1968), Paraguay (ARANDA \& Flechtmann 1969; FLECHTMANN 1973). 


\section{Tydeus sp.}

Specimens examined. Brazil, São Paulo: São José do Rio Preto (Sítio Santo Antonio), three females, VI-21 and VII-23-1990.

\section{Tetranychidae Donnadieu, 1875}

\section{Monoceronychus bambusicola, sp.n.}

\section{Figs 1-9}

Diagnosis. This species resembles M. linki Pritchard \& Baker, 1955; however, differs in shape of the distal enlargement of prodorsal frontal-medium prominence. In the male the setae hl (fifth pair of dorsocentral) are equal in shape to the other dorsal setae (spatulate or subspatulate); in the female they are flagellate and pubescent.

Female. Measurements $(n=9)$ - Body length 477 (451-495); width 221 (198-231). Yellowish-green when alive. Dorsum (Fig. 1): Integument granulated forming ring ornamentations, more emphasized on prodorsum and opisthosoma; between these regions, the integument exhibits slender transversal furrows with less obvious granules. Frontal medium prominence of prodorsum ending enlarged. Dorsal setae spatulate and serrate, except setae hl (fifth pair of dorsocentral setae) which are flagellate and pubescent. Gnathosoma: Stylophore conic and narrow, about 1.5 times as long as hroad. Peritremes short and ending in anastomosed chambers. Legs (Figs 2-3): Chaetotaxy (from coxa to tarsus)- I: 2-1-9-2 or 3-8 (2)-9+2 duplex, II: 2-I-5-3-4-8+ 1 duplex, III: 1-1-2-4-3-7, IV: 1-0-2-4-3-7 (1).

Male. Measurements $(n=2)$ : body length 358 (352-363), width 160 (154165). Similar to female, but less robust and idiosoma tapering posteriorly; setae h1 spatulate and serrate (Fig. 4); legs proportionaly longer. Legs (Figs 6-7): Chaetotaxy (from coxa to tarsus) I: 2-1-9-2-8 (3)-10 (3) + 2 duplex, II: 2-1-5-3-4-9 (1) + 1 duplex, III: 1-1-2-4-3-7, IV: 1-0-2-4-3-7 (1). Aedeagus (Figs 5, 8): Long and rectiliniar, distal third gradualy narrowing ending in an acute tip.

Deutonymph. Measurements $(\mathrm{n}=2)$ : body length 396 (385-407), width 190 (187-193). Similar to female. Legs: chaetotaxy (from coxa to tarsus)- 1:2-1-6-2 or 3-4 (1)-9+2 duplex, II: 2-1-3-2-4-7+ 1 duplex, III: 1-1-2-1-3-7, IV: 1-0-2-1-3-7.

Protonymph. Measurements $(n=3)$ : body length 304 (264-352), width 137 (132-143). Similar to deutonymph. Legs: Chaetotaxy (from coxa to tarsus) - I: 2-0-3-2-4 (1)-7+2 duplex, II: 1-0-2-2-4-7+1 duplex, III: 1-0-2-1-3-5, IV: $0-0-2-1-3-5$.

Larva. Measurements $(n=2)$ : body length 259 (253-264), width 132. Dorsum (Fig. 9): Without frontal prodorsal prominence typical of the species of this genus. Legs: Chaetotaxy (from coxa to tarsus) I: 1-0-3-2-4 (1)-7+1 duplex, II: 0-0-2-2-4-7+ 1 duplex, III: 0-0-2-1-3-5.

Ecological data. Inhabits the lower leaf surface, where it may be confused with necrotic spots, due to fungus attack (helminthosporiosis). Small populations; 


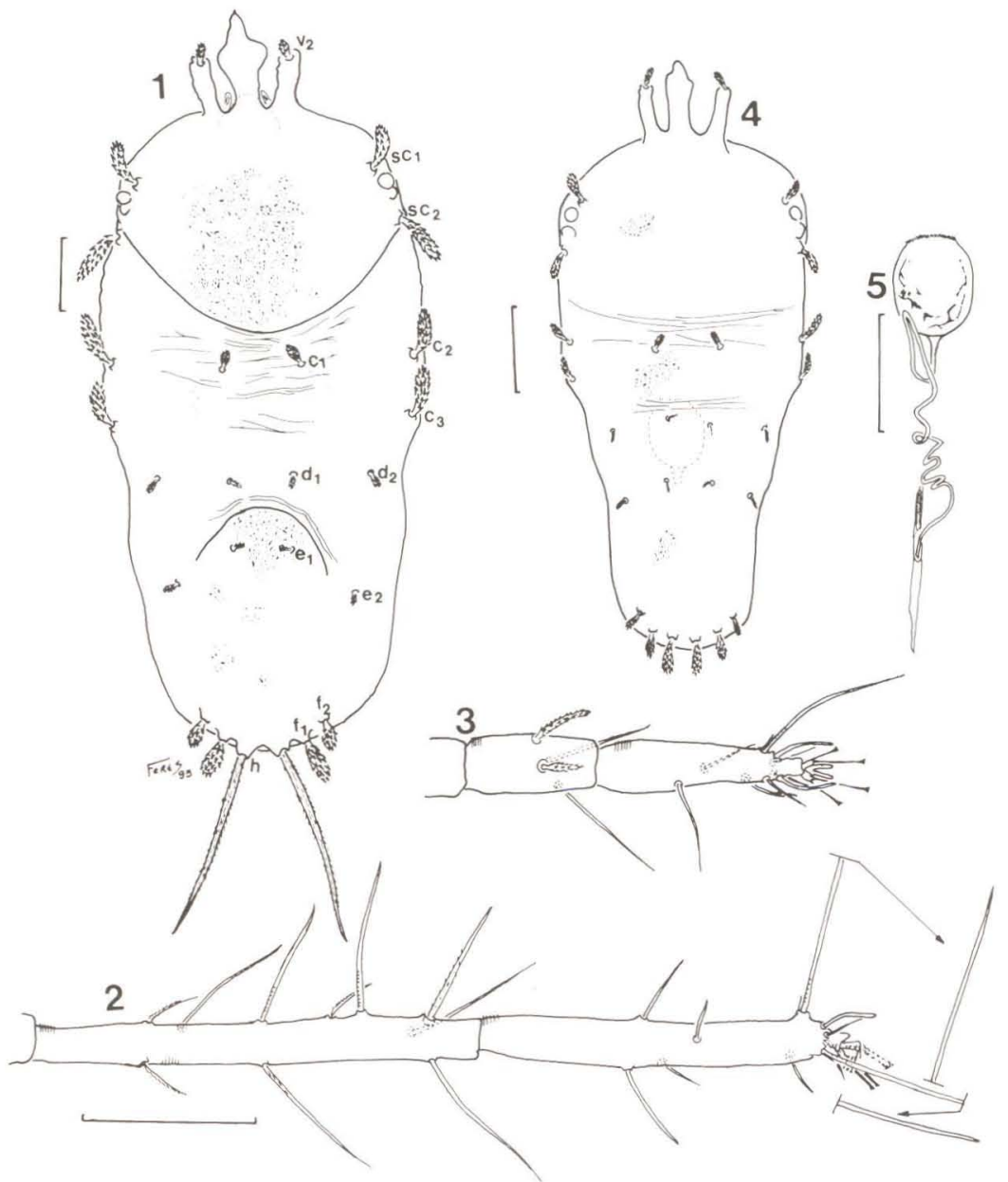

Figs 1-5. Monoceronychus bambusicola, sp.n.. (1-4) Female. (1) Dorsal view [setal nomenclature as used after Grandjean, 1939 according to LINDQUIST (1985)]; (2) tibia and tarsus I; (3) tibia and tarsus II. (4-5) Male. (4) Dorsal view; (5) genital system detail. Scale bar $=50 \mu \mathrm{m}$.

only few specimens were found on a large number of examined leaves.

Holotype female. Brazil, São Paulo: São José do Rio Preto (Sítio Santo Antonio), ex. Bambusa sp. (Poaceae), V-28-1990. Paratypes one female and one larva, same data as holotype; four females, two males, two deutonymphs and one larva, VI-21-1990; three females and three protonymphs, VI-06-1991, same host and local as holotype.

Remark. Two females and one deutonymph exhibited an extra tactile setae on genu I. Two stout dorsolateral setae are always present; the extra tactile setae is ventral and filiform. 


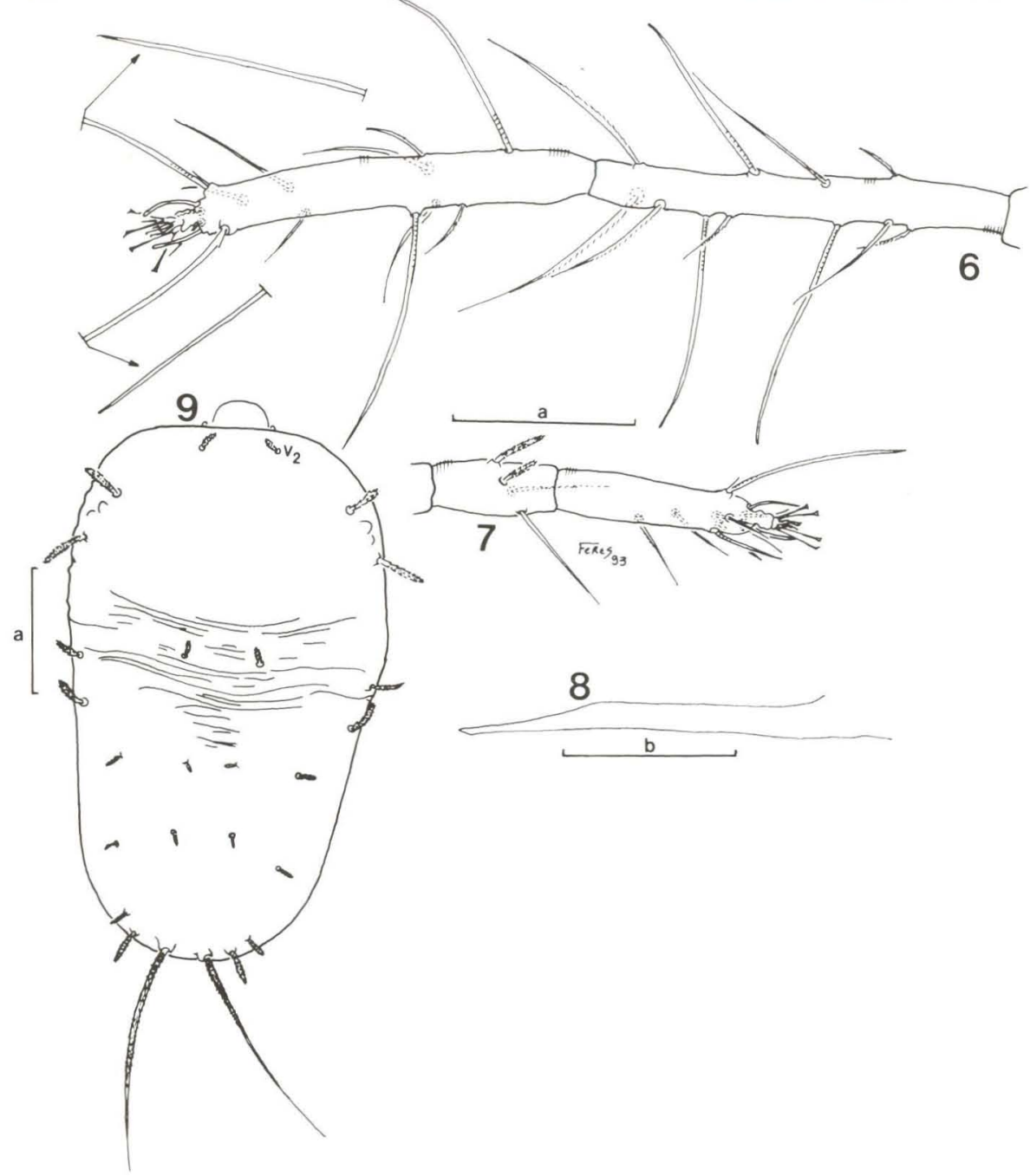

Figs 6-9. Monoceronychus bambusicola, sp.n.. (6-8) Male. (6) Tibia and tarsus I; (7) tibia and tarsus II; (8) aedeagus. (9) Larva dorsal view. Scale bar $a=50 \mu \mathrm{m}, \mathrm{b}=20 \mu \mathrm{m}$.

\section{Schizotetranychus longirostris, sp.n.}

Figs 10-20

Diagnosis. This species resembles Schizotetranychus parasemus Pritchard \& Baker, 1955 however it has a longer rostrum, reaching end of tibia I (in $S$. parasemus reaching end of femur I); tibia I and II with four and five setae respectively (six and seven respectively in $S$. parasemus). Lightly dorso-ventrally flattened. 


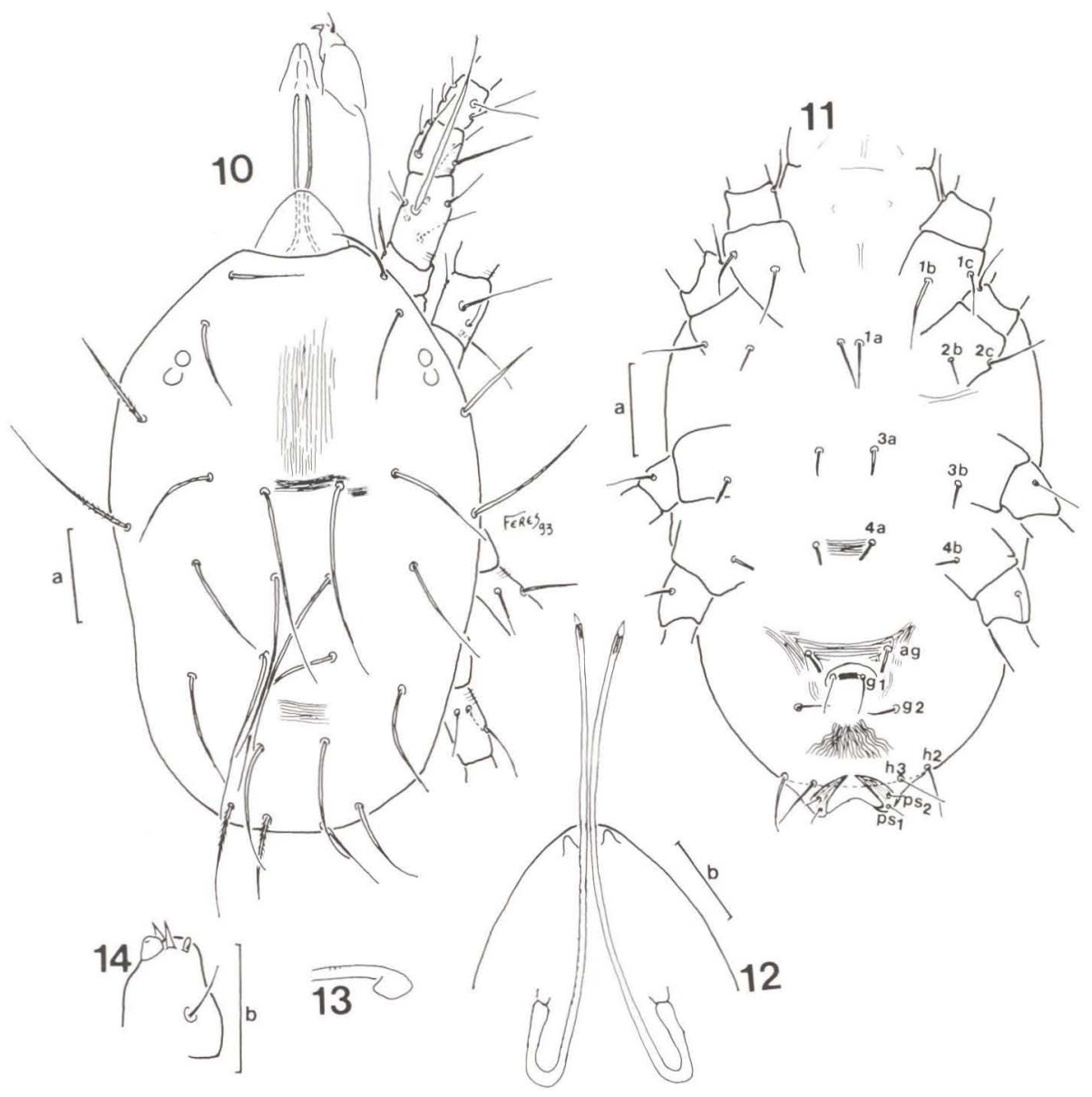

Figs 10-14. Schizotetranychus longirostris, sp.n., female. (10) Dorsal view; (11) ventral view [setal nomenclature as used after Grandjean, 1939 according to LINDQUIST (1985)]; (12) ventral view of the stylophore; (13) peritreme; (14) palptarsus. Scale bar a $=50 \mu \mathrm{m}$, $b=20 \mu \mathrm{m}$.

Female. Measurements $(n=27)$ : body length 455 (407-495); width 223 (198-253). Green when alive. Dorsum (Fig. 10): Prodorsum with longitudinal striae and opisthosoma finely striated transversely. Dorsal idiosomal setae set directly on integument, slender and pilose; the opisthosomal setae about twice as long as distance between basis of consecutive setae; setae v2, sc1 and sc2 (prodorsals) are smaller and setae sc2, c3, $\mathrm{f} 2$ and $\mathrm{h} 1$ more pubescent than others. Ventral (Fig. 11): Setae 3a, 4a, ag, 2b, 3b and 4b, smaller and thicker than other ventral setae. Genital flap and area immediately anterior transversely striated; striae ligther on genital flap than remaining ventral region. Gnathosoma: Stylophore conic and some specimens exhibit a short ventral furrow flanked by 


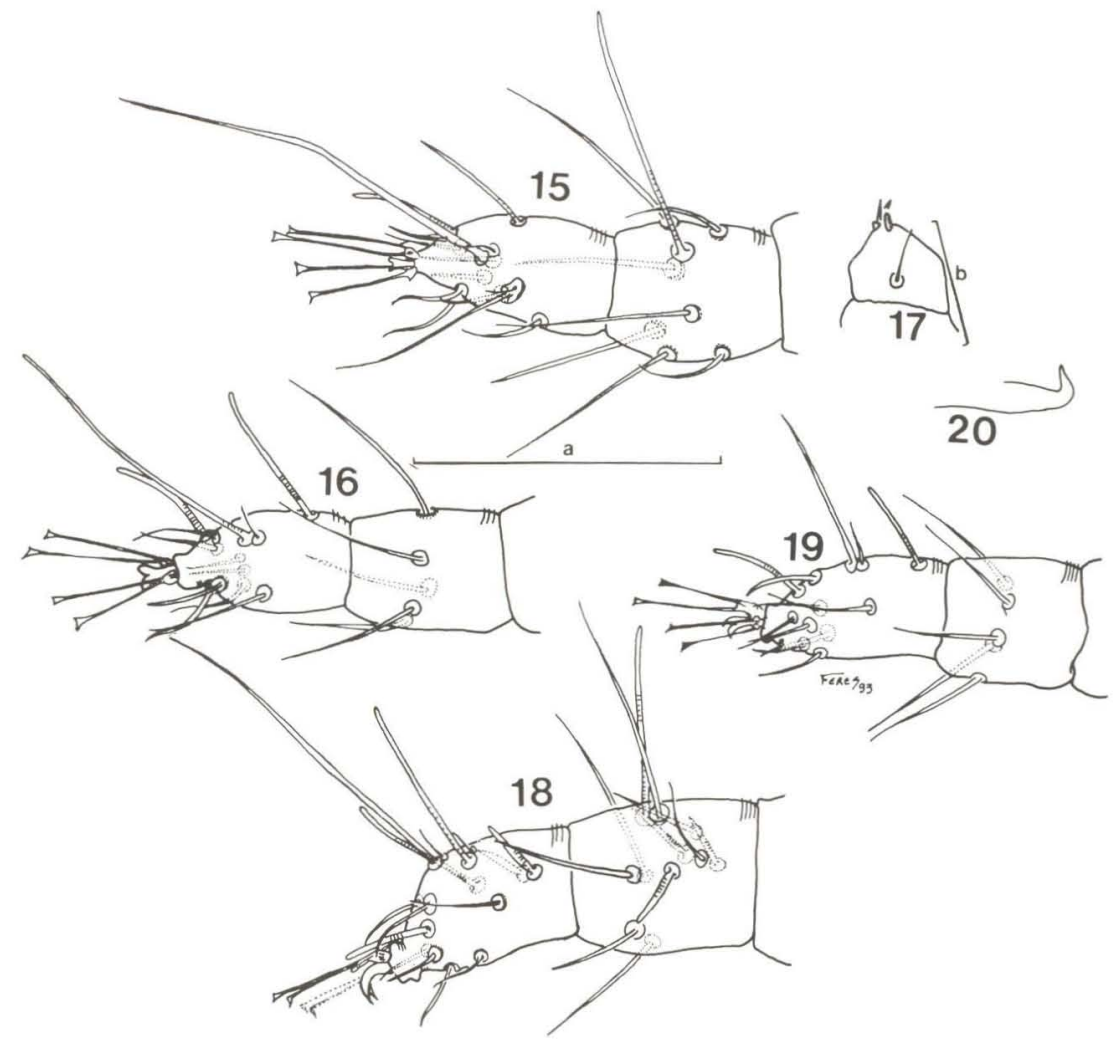

Figs 15-20. Schizotetranychus longirostris, sp.n.. (15-16) Female. (15) Tibia and tarsus I; (16) tibia and tarsus II. (17-20) Male. (17) Palptarsus; (18) tibia and tarsus I; (19) tibia and tarsus II; (20) aedeagus. Scale bar $a=50 \mu \mathrm{m}, \mathrm{b}=20 \mathrm{~m} \mu$.

two conic evaginations, in which slide the whiplike cheliceral stylets (Fig. 12). Peritremes slightly bent, ending in a small hook (Fig. 13). Terminal sensillum of palp tarsus round, with a small depression on apical region, as long as wide; proximal sensillum small, fusiform, twice as long as broad (Fig. 14). Legs (Figs 15-16): Chaetotaxy (from coxa to tarsus)- I: 2-1-8-5-7 (1)-8 (2)+2 duplex, II: 2-1-5-5-5-8 (2)+ 1 duplex, III: 1-1-3-3-4-7 (1), IV: 1-1-3-3-5-7 (1). Tarsus I with 1 tactile seta and 1 solenidion proximal to duplex setae; tarsus II with 1 solenidion proximal to duplex setae.

Male. Measurements: body length $(n=8) 318$ (297-341); width $(n=7) 170$ (165-176).

Gnathosoma. Terminal sensillum reduced, conic, as long as base width; proximal sensillum cylindrical, 2.5 times as long as wide (Fig. 17). Legs (Figs 18-19): Chaetotaxy (from coxa to tarsus) I: 2-1-8-5-7 (4)-8 (4) +2 duplex, II: 2-1-5-5-5-8 (2)+1 duplex, III: 1-1-3-3-4-7 (1), IV 1-1-3-3-5-7 (1). Tarsus I with one tactile seta and two solenidia proximal to duplex setae; tarsus II with one 
solenidion proximal to duplex setae. Aedeagus (Fig. 20): Curved dorsad at a slightly acute angle, ending in a short neck as figured.

Ecological data. This species inhabits the lower leaf surface, forming web nests (life type WN sensu SaITO 1983). The web nests were constructed more often along the main veins, which were used as supporter for the more elevated area of the nest.

Holotype male, ex. Bambusa sp. (Poaceae). Brazil, São Paulo: São José do Rio Preto (Sítio Santo Antonio), IV-26-1990. Paratypes five females, two males, two deutony mphs and one protony mph, V-28-1990; five females, two males and one deutonymph, VI-21-1990 and 17 females, three males, 20 deutonymphs and eight protonymphs, VII-23-1990, some host and local as holotype.

\section{Schizotetranychus paraelymus, sp.n.}

\section{Figs 21-26}

Diagnosis. This species resembles Schizotetranychus elymus McGregor, 1950 in having the majority of opisthosomal setae similar in length $(35-38 \mu \mathrm{m})$, however differs by the large length $(62-65 \mu \mathrm{m})$ of setae $\mathrm{c} 3$ (humeral) and setae sc2 (third pair of prodorsal) which attain $40-43 \mu \mathrm{m}$. It also differs in the chaetotaxy of tibia and tarsus I.

Female. Measurements: body length $(n=5) 297$ (275-319), width $(n=4)$ 148 (132-165). Greenish when alive.

Dorsum (Fig. 21). Finely striated, prodorsum with longitudinal and opisthosoma with transversal striae. Dorsal setae set directly on integument, slender, pubescent and sub-equal in length $(35-38 \mu \mathrm{m})$, except setae sc2 (third pair of prodorsal) $(40-43 \mu \mathrm{m})$ and $\mathrm{c} 3$ (humeral) $(62-65 \mu \mathrm{m})$.

Ventral. Setae long and filiform; setae $1 \mathrm{~b}$ and $2 \mathrm{c}$ about 2-3 times longer than other ventral setae; setae $1 \mathrm{c}$ and $2 \mathrm{c}$ visibly pubescent. Genital flap transversally striated, area immediately anterior longitudinally striated with irregular striation pattern (Fig. 22). Gnathosoma. Stylophore conic. Peritreme slightly bent (Fig. 23). Terminal sensillum of palptarsus cylindrical, ending in a cone; proximal sensillum cylindrical, about twice as long as broad (Fig. 24). Legs (Figs 25-26): Chaetotaxy (from coxa to tarsus)- I: 2-1-7-5-7 (1)-9 (2) + 2 duplex, II: 2-1-5-5-5-9 (2) +1 duplex, III: 1-1-3-3-4-5 (1), IV: 1-1-2-3-5-5 (1). Tarsus I with one tactile seta and one solenidion proximal to duplex setae; tarsus II with one solenidion proximal to duplex setae.

Male. Unknown.

Ecological data. Inhahits the lower leat surface.

Holotype female. Brazil, Sào Paulo: São José do Rio Preto (Sítio Santo Antonio), ex. Bambusa sp. (Poaceae), XI-16-1989. Paratypes two females, XI-16-1989; one female, V-28 and one female VI-21-1990, on same host and local as holotype.

Remarks. Schizotetranychus longirostris and S. paraelymus, were synchronous and syntopicous on Bambusa sp. Collectings with finality to estimate 
individual numbers for specimens from the two populations, showed a ratio of $9.5 / 1$ respectively.

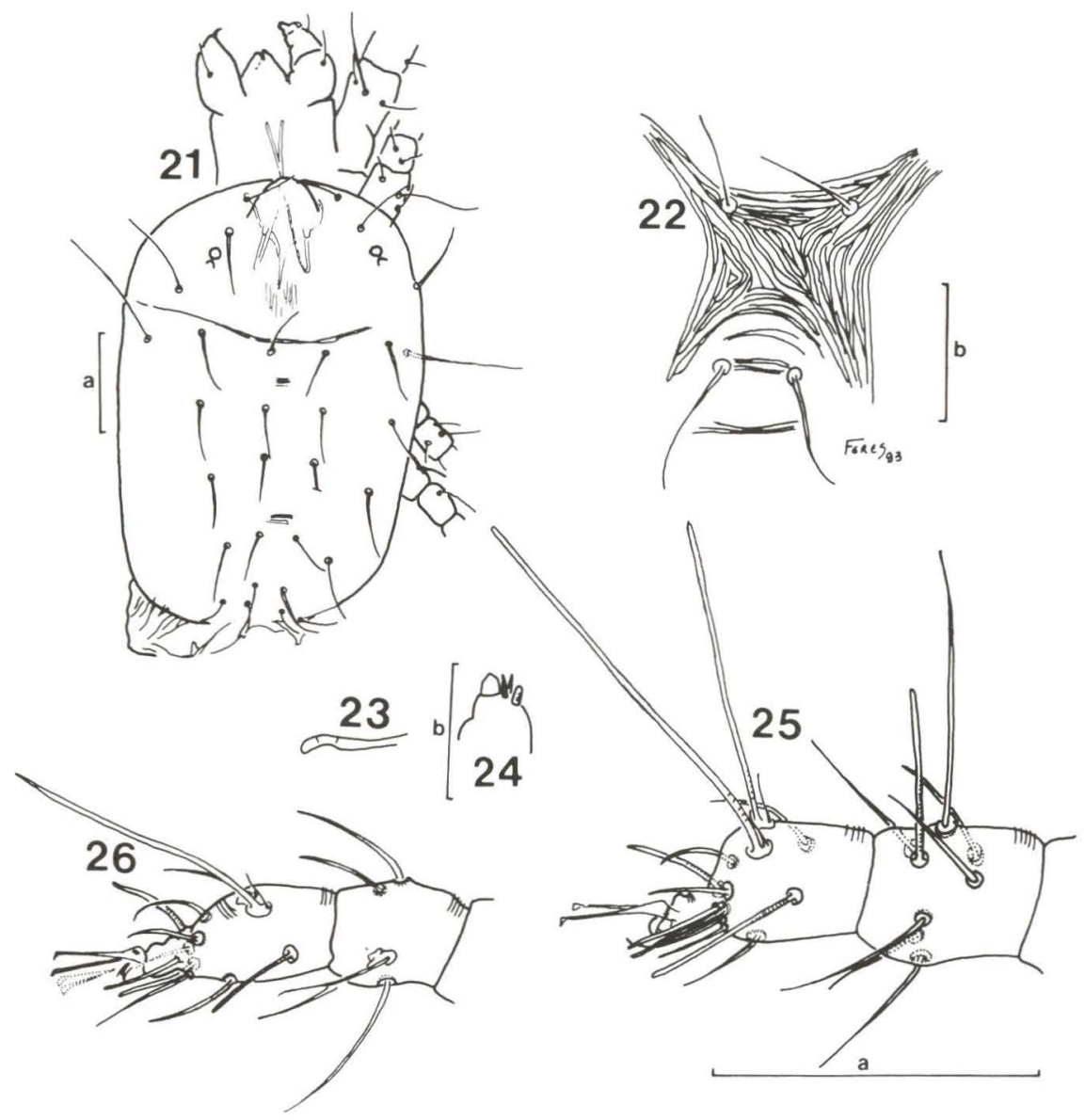

Figs 21-26. Schizotetranychus paraelymus, sp.n., female. (21) Dorsal view; (22) genital flap and area immediately anterior; (23) peritreme; (24) palptarsus; (25) tibia and tarsus I; (26) tibia and tarsus II. Scale bar $a=50 \mu \mathrm{m}, b=20 \mu \mathrm{m}$.

\section{Oligonychus santoantoniensis, sp.n.}

Figs 27-34

Diagnosis. This species resembles Oligonychus ununguis (Jacobi, 1905) and $O$. punicae (Hirst, 1926) which occur on conifers and broad-leaved tropical plants, respectively, but differs in shape of the aedeagus, which exhibits the neck forming an acute angle with shaft axis. 


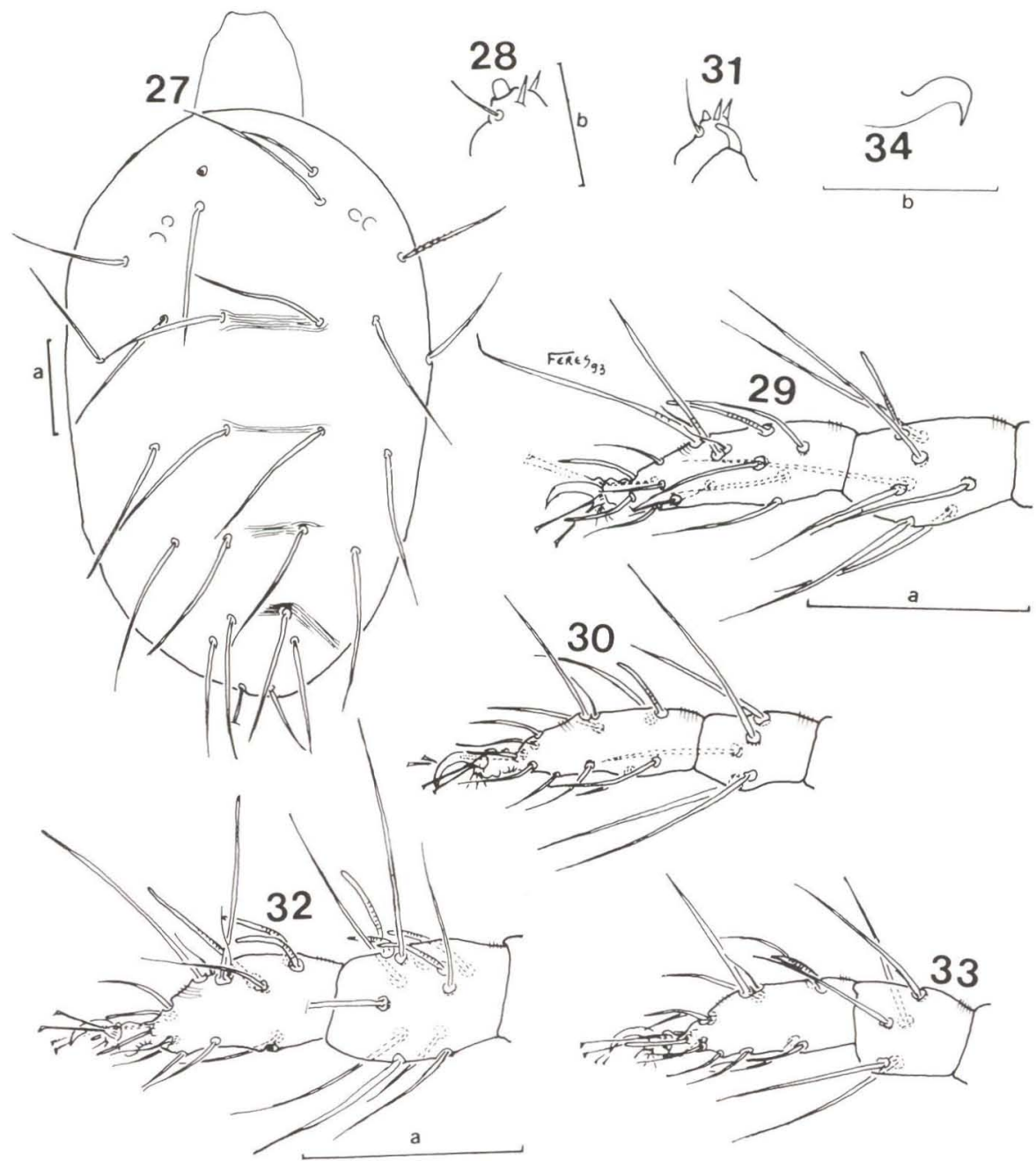

Figs 27-34. Oligonychus santoantoniensis, sp.n.. (27-30) Female. (27) Dorsal view; (28) palptarsus; (29) tibia and tarsus I; (30) tibia and tarsus II. (31-34) Male. (31) Palptarsus; (32) tibia and tarsus $I_{;}(33)$ tibia and tarsus II; (34) aedeagus. Scale bar $a=50 \mu \mathrm{m}, b=20 \mu \mathrm{m}$.

Female. Measurements $(n=6)$ : body length 363 (341-385), width 202 (187-220).

Dorsum (Fig. 27). Prodorsum longitudinally striated and opisthosoma transversally striated, rounded lobes on striae, more wider than long and spaced. Dorsal idiosomal setae set directly on integument, slender, pubescent and longer than distances between basis of consecutive setae.

Ventral. Genital flap transverselly striated and area immediately anterior longitudinally striated. Gnathosoma: Stylophore conic with slight invagination on 
distal end. Peritremes straight, ending in a simple bulb. Terminal sensillum of palptarsus cylindrical and rounding on distal end, about as long as wide; proximal sensillum not evident (Fig. 28). Legs (Figs 29-30): Chaetotaxy (from coxa to tarsus) I: 2-1-8-5-7 (1)-12 (1)+2 duplex, II: 2-1-6-5-5-12 (1)+1 duplex, III: 1-1-2-2-5-9 (1), IV: 1-1-1 or 2-2-5-8 (1). Tarsus I with four tactile setae and one solenidion proximal to duplex setae; tarsus II with three tactile setae and one solenidion proximal to duplex setae. With I tactile seta on venter beyond duplex.

Male. Measurements $(n=5)$ : body length 310 (297-319).

Gnathosoma. Terminal sensillum of palptarsus reduced, conic, about as long as wide at base; proximal sensillum not evident (Fig. 31). Legs (Figs 32-33): Chaetotaxy (from coxa to tarsus)- I: $2-1-8-5-7$ for 8 (4)-11 (3)+2 duplex, II: 2-1-6-5-5-12 (1) + 1 duplex, III: 1-1-2-2-5-8 (1), IV: 1-1-1-2-5-8 (1). Tarsus I with three tactile setae and three solenidia proximal to duplex; tarsus II with three tactile setae and 1 solenidion proximal to duplex setae. Empodia as in female, however smaller. Aedeagus (Fig. 34): Shaft elongate with a short neck, curved ventrally, gradually thinning until ending in an acute tip.

Deutonymph. Measurements: body length $(n=8) 273$ (242-308), width $(n=5) 173$ (165-187).

Legs. Chaetotaxy (from coxa to tarsus)- I: 2-1-6-5-6 (1)-9 (1) + 2 duplex, II: 2-1-3-5-5-9+ I duplex, III: 1-1-2-2-5-7 (1), IV: 1-0-1-2-5-7.

Protonymph. Measurements $(\mathrm{n}=1)$ : body length 198; width 143.

Legs. Chaetotaxy (from coxa to tarsus)- I: 2-?-3-4-5 (1)-8+2 duplex, II: 1-?-3-4-5-8+ 1 duplex, III: 1-?-2-2-5-7, IV 0-?-1-2-5-5.

Larva. Unknown.

Ecological data. Inhabits the upper leaf surface. No webbing was observed.

Holotype male. Brazil, São Paulo: São José do Rio Preto (Sítio Santo Antonio), ex. Bambusa sp. (Poaceae), VI-23-1990. Paratypes three females and five deutonymphs, VI-21-1990; three females, four males, two deutonymphs and one protonymph, VII-23-1990, some host and local as holotype.

\section{Winterschmidtiidae Oudemans, 1923}

\section{Czenspinskia sp.}

Especimens examined. Brazil, São Paulo: São José do Rio Preto (Sítio Santo Antonio), five females, one male and two nymphs, IV-26-1990; three females, V-23-1990; five females, VI-21-1990 and six females and one nymph, VII-23-1990.

Acknowledgments. To Dr. Gilherto J. de Morais (CNPMA-EMBRAPA. Jaguariúna, São Paulo. Brasil) for his help dealing with phytoseiid mites identification. 


\section{REFERENCES}

ARANDA C, B.R. \& C.H.W. Flechtmann. 1969. Ácaros do gênero Lorryia no Brasil e Paraguay. Res. II Reun. An. Soc. Brasil. Entomol., Recife: 41-42. BAKER, E.W. 1949. A review of the mites of the family Cheyletidae in United States National Museum. Proc. U.S. Natl. Mus. 99 (3238): 267-320. . 1968. The genus Lorryia. Ann. Entomol. Soc. Amer. 61 (4):986-1008.

ChANT, D.A. 1965. Generic concepts in the family Phytoseiidae (Acarina: Mesostigmata). Canad. Ent. 97: 351-374.

Chant, D.A. \& E. Yoshida- Shaul. 1986. A new subfamily, Cydnodromellinae, in the family Phytoseiidae (Acari: Gamasina). Canad. Jour. Zool. 64: 2811-2823.

Chant, D.A.; R.S.C. Hansell; H.J. Rowell \& E. Yoshida-Shaul. 1978. A study of the family Phytoseidae (Acarina: Mesostigmata) using the methods of numerical taxonomy. Canad. J. Zool. 56: 1330-1347.

CoOreman, J. 1958. Notes et observations sur les Acariens. VII- Photia graeca n.sp. (Acaridiae, Canestriniidae) et Lorryia formosa n.sp. (Stomatostigmata, Tydeidae). Bull. Inst. Roy. Sci. Nat. Belgique 34 (8): 1-10.

Denmark, H.A. \& M.H. Muma. 1970. Some phytoseiid mites of Paraguay (Phytoseiidae:Acarina). Florida. Ent. 53 (4): 219-227. 1972. Some Phytoseiidae of Colombia (Acarina:Phytoseiidae). Florida. Ent. 55 (1): 19-29.

1973. Phytoseiidae mites of Brazil (Acarina:Phytoseiidae). Rev. Brasil. Biol. 33: 235-276.

1975. The Phytoseiidae (Acarina:Mesostigmata) of Puerto Rico. J. Agric. Univ. Puerto Rico 59: 279-304.

Flechtmann, C.H.W. 1971. Alguns trombidiformes do Brasil e do Paraguai (Acari). Livre Docência Thesis, not publicated, Escola Superior de Agricultura Luiz de Queiroz, Piracicaba, 63p.

1973. Lorryia formosa Cooremann, 1958 - Um ácaro dos citros pouco conhecido no Brasil. Ciência e Cultura 25 (12): 1179-1181.

Grandiean, F. 1939. Les segments post-larvaires de l'hystérosoma chez les Oribates (Acariens). Bull. Soc. Zool. France 64: 273-284.

JEPPSON, L.R.; H.H. KEIFER \& E.W. BAKER. 1975. Mites injurious to economic plants. Berkeley and Los Angeles, University of California Press, XXIV +641p.

LINDQUiST, E.E. 1985. Anatomy, Phylogeny and Systematics. 1.1.1. External Anatomy, p. 3-28. In: W. HeLlE \& M.W. SABELIS (eds). Spiders mites. their Biology, Natural enemies and control. Amsterdam, Elsevier Science Publishers B.V., vol. 1A.

MCMurtry, J.A. 1983. Phytoseiid mites from Guatemala, with descriptions of two new species and redefinitions of the genera Euseius, Typhloseiopsis and the Thyphlodromus occidentalis species group (Acari: Mesostigmata). Internat. J. Ent. 25: 249-272. 
Moraes, G.J. \& J.A. MCMurtry. 1983. Phytoseiid mites (Acarina) of northeastern Brazil with descriptions of four new species. Internat. J. Acarol. 9: 131-148.

Moraes, G.J.; J.A. McMurtry \& M.D. Denmark. 1986. A Catalog of the mite family Phytoseiidae: references to taxonomy, synonymy, distribution and habitat. Brasilia, EMBRAPA-DDT, 353p.

Moraes, G.J. \& N.C. Mesa. 1988. Mites of the family Phytoseiidae (Acari) in Colombia. with descriptions of the three new species. Internat. J. Acarol. 14 (2): 71-88.

Moraes, G.J.; N.C. Mesa \& A. Braun. 1991. Some Phytoseiid mites of Latin America (Acari: Phytoseiidae). Internat. J. Acarol. 17 (2): 117-137.

Muma, M.H. 1964. Cheyletidae (Acarina:Trombidiformes) associated with citrus in Florida. Florida Ent. 47 (4): 239-253.

Rodrigues, M. DE C. 1968. Acarina de Moçambique. Aggron. moçamb. 2 (4): 215-256.

Rowell, H.J.; D.A. Chant \& R.I.C. Hansell. 1978. The determination of setal homologies and setal patterns on the dorsal shield in the family Phytoseiidae (Acarina: Mesostigmata). Can. Ent. 110: 859-876.

SaITo, Y. 1983. The concept of "life types" in Tetranychinae. An attempt to classify the spinning behavior of Tetranychinae. Acarologia 24 (4): 377-391. Summers, F.M. \& D.W. PriCE. 1970. Revision of the family Cheyletidae. Univ. Calif. Publ. Ent. 61: 1-153.

Volgin, V.I. 1955. Acarina of rodents of the USSR fauna. Acad. Nauk. SSSR, Zool. Inst. Opredelitelipo Faune SSSR 59: 1-459. 